ENTREPRENEURSHIP AND SUSTAINABILITY ISSUES

ISSN 2345-0282 (online) http://jssidoi.org/jesi/

2021 Volume 8 Number 4 (June)

http://doi.org/10.9770/jesi.2021.8.4(41)

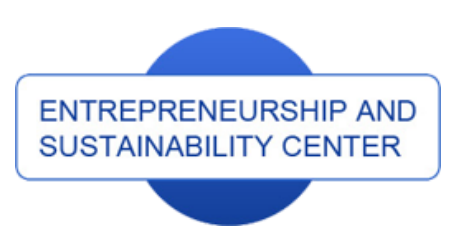

Publisher

$\underline{\text { http://jssidoi.org/esc/home }}$
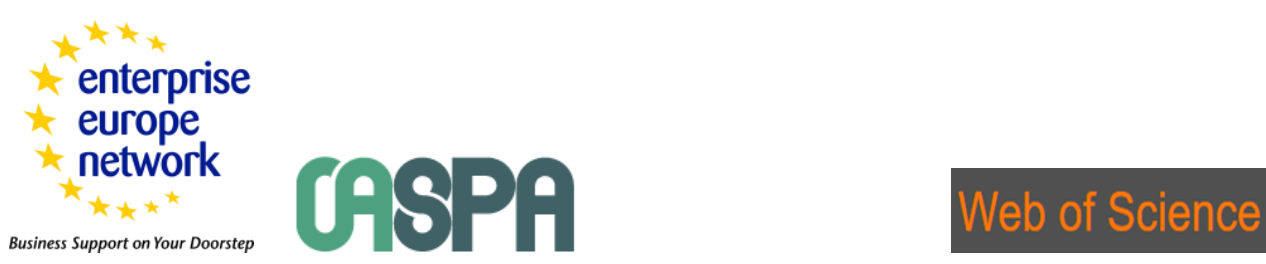

1) Clarivate

\title{
LEGITIMIZATION OF INCOME OF CLIENTS AS A FACTOR OF FINANCIAL STABILITY OF BANKS
}

\author{
Stanislav Zlyvko ${ }^{1 *}$, Serhii Shkliar ${ }^{2}$, Anatoliy Kovalenko ${ }^{3}$, Maksym Sykal ${ }^{4}$, Oleksandr Snigerov ${ }^{5}$ \\ ${ }^{1,3}$ Academy of the State Penitentiary Service, Honcha str. 34, Chernihiv, 14000, Ukraine \\ ${ }^{2}$ Arzinger Law Firm, Moskovskaya Street, 32/2, Kyiv, 01010, Ukraine \\ ${ }^{4}$ Private Institution of Higher Education, Kyiv International University, vulytsia Lvivska, 49, Kyiv, 03179, Ukraine \\ ${ }^{5}$ Principal Researcher at the Hon. Prof. M. S. Bokarius Kharkiv Research Institute of Forensic Examinations of the Ministry \\ of Justice of Ukraine 8a, Zolochivska Str., Kharkiv, 61177, Ukraine \\ E-mails: ${ }^{{ }^{*}}$ zlyvko@ukr.net
}

Received 15 February 2021; accepted 5 May 2021; published 30 June 2021

\begin{abstract}
Prevention and counteraction to money laundering by bank clients are the most important links in the fight against money laundering among all entities of primary financial monitoring: reports of banks on suspicious financial transactions account for $96-98 \%$ of the total number of reports to the State Financial Monitoring Service of Ukraine. An important step in further development and improvement of the system of prevention and counteraction to money laundering of the banks clients is its evaluation and identification of weaknesses. Cash transactions and cash flows through the accounts of bank clients are the most risky group of services of banking institutions in terms of money laundering. The analysis of statistical characteristics of the series of dynamics of cash turnover, turnover of funds on accounts at the request of economic entities, turnover of funds on accounts at the request of individuals of 96 banks of Ukraine showed that banks in which activity the National Bank of Ukraine (NBU) detect fraudulent operation with signs of money laundering, have significantly higher values of the coefficient of variation of cash flows, on average $46 \%$, compared to banks in which the NBU did not detect fraudulent operations, but did detect violations, for which it applied measures of influence, and in comparison with banks to which no measures of influence were applied. The results of the analysis proved that the coefficient of variation can be used as an indicator of the level of risk of money laundering by the bank clients, which allows to significantly facilitate and reduce the duration of analysis of bank financial performance within rapid testing for money laundering.
\end{abstract}

Keywords: money laundering; shadow economy; business activity; stability; risk

Reference to this paper should be made as follows: Zlyvko, S., Shkliar, S., Kovalenko, A., Sykal, M., Snigerov, O. 2021. Legitimization of income of clients as a factor of financial stability of banks. Entrepreneurship and Sustainability Issues, 8(4), 668-681. http://doi.org/10.9770/jesi.2021.8.4(41)

JEL Classifications: K22, L21 


\section{ENTREPRENEURSHIP AND SUSTAINABILITY ISSUES}

ISSN 2345-0282 (online) http://jssidoi.org/jesi/

2021 Volume 8 Number 4 (June)

http://doi.org/10.9770/jesi.2021.8.4(41)

\section{Introduction}

Legitimization of incomes from crime is a significant threat to the stability of the economy of any country, it significantly reduces the financial security of the state and increases the risk of global socio-economic and political instability. Awareness of this threat encourages the international community to develop and implement appropriate measures to limit and prevent money laundering. However, the rapid development of information technology, increasing the mobility of financial resources, virtualization of certain types of business activities require constant improvement of processes and tools to prevent and combat money laundering.

Leading professionals, specialists and experts on money laundering are aware that most counteraction mechanisms are developed ex post facto, i.e. after the identification and definition of typological schemes and methods of money laundering, and often after a series of specially conducted investigations and relevant court decisions (Jaara \& Kadomi 2017; Kriviňš et. al 2021). In this regard, it is almost impossible to talk about the existence of effective and well-functioning preventive or precautionary measures: when the general public becomes aware of an improved or new scheme or method of money laundering, criminals find new ways to withdraw funds from the shadow economy (Habibzadeh 2016). The process of combating money laundering is complicated by the fact that the schemes of money laundering, as a rule, have a significant number of participants subordinated to various departments, ministries, and often states (Chong \& Lopez-De-Silanes 2015). Therefore, the state system of financial monitoring, which is designed to combat money laundering, coordinate the activities of various entities, includes in its structure public authorities of various branches and a wide range of primary level entities.

One of the leading roles among the entities of primary financial monitoring belongs to banking institutions, which carry out the vast majority of cash transactions within Ukraine and provide $96 \%$ or more of information on suspicious financial transactions. Only in 2017-2018, there was detected legitimization of UAH 33.26 billion using banking services. For these reasons, the issue of preventing and counteracting the legitimization of income of bank clients is always relevant, and for the proper implementation of the functions of internal financial monitoring it is necessary to create effective systems to prevent and combat legitimization of income.

The issue of preventing and combating legitimization (laundering) of proceeds from crime is among the key ones in the context of ensuring economic security of both Ukraine and the world. The rapid development of information technology, in particular in the field of financial technology, has contributed to the complexity of criminal schemes and the emergence of new tools for money laundering. In the process of European integration, Ukraine has undertaken a number of commitments to combat money laundering.

However, the process of development of the legal framework, as well as methodical support for combating money laundering in Ukraine is not yet complete. In view of this, it is important to develop and improve the theoretical basis for preventing and combating legitimization (laundering) of proceeds from crime.

\section{Literature review}

Despite the significant results of scientific studies in the field of prevention and counteraction to legitimization (laundering) of proceeds from crime, the issues of combating money laundering remain insufficiently developed, taking into account the specifics of banking institutions. For example, the Regulation on Implementing the Financial Monitoring by Banks (2015) adopted to prevent the use of the banking system for legitimization (laundering) of proceeds from crime, terrorist financing and the financing of the proliferation of weapons of mass destruction has no definition of the concept of legitimization of criminal proceeds/terrorist financing by a bank client. There is no definition of the concept of legitimization of income in the main law - the Law of Ukraine "On Prevention and Counteraction to Legalization (Laundering) of Proceeds from Crime, Financing of Terrorism 


\section{ENTREPRENEURSHIP AND SUSTAINABILITY ISSUES}

ISSN 2345-0282 (online) http://jssidoi.org/jesi/

2021 Volume 8 Number 4 (June)

http://doi.org/10.9770/jesi.2021.8.4(41)

and Financing of Proliferation of Weapons of Mass Destruction" (2014), although it is the main concept appears in the text of the law almost 200 times, which is on average 3-4 times per page.

In this regard, the question arises about the quality and effectiveness of the measures developed to prevent and combat legitimization, because if there is no definition of the basic concept, then what exactly are the appropriate measures aimed at, what is the core of the financial monitoring system, what is the fight led with (Sobreira et. al 2019).

Based on the analysis carried out by the authors, we can identify the main morphological components of the concept of "legitimization of income": it is defined as a process or set of actions, methods, techniques, financial transactions, agreements, etc. (Dreżewski et. al 2015); it occurs after the commission of the "main" (predicate) crime (Teichmann 2020); it aims to hide the sources of funds for their further use in the process of legitimate economic activity (Tsingou 2018).

It should be noted that the presence of a predicate crime is the basis for the recognition of income as illegal and for the definition of the related financial transactions as legitimization (laundering) of income.

A separate issue in determining the content of the concept of legitimization of income is to establish its relationship with the main (predicate) crime, i.e. socially dangerous, illegal actions, as a result of which there appears a criminal income, which is then subject to legitimization. Summing up the views of the authors (Isa et. al 2015; Singh \& Best 2019), we can say that there are two main provisions regarding this issue. The first provision is that money laundering should be considered as a separate crime committed using a two-, three-, four-phase scheme.

However, at each stage of these schemes there is no connection with the predicate crime, which determines the method and mechanism of money laundering. Such approach assumes that money laundering is a separate crime in relation to the primary crime of obtaining it, and therefore an indication of the "criminal nature" of the origin of such money (income) must be contained directly in the concept - "legitimization of proceeds of crime".

The second provision on the relationship between money laundering and the main predicate crime involves the introduction of the so-called "zero phase" into the money laundering schemes, which is associated with the commission of a predicate crime. Such approach is used by the SCFM of Ukraine (Current methods and ways of legitimization (laundering) of proceeds from crime and terrorist financing, 2014). Under such conditions, it is clear by default that only criminal proceeds will be legitimized. It is such approach to understanding the essence of the concept of "legitimization of income" that is the basis of the study presented in the dissertation.

That is, in summary, we can say that the legitimization of income of bank clients already implies the fact that the crime was committed, and refers only to the incomes of bank clients, which were obtained by criminal way.

An important aspect of further development of the system of prevention and counteraction to legitimization of income of bank clients is substantiation of definitions of concepts of "prevention of legitimization of income of bank clients" and "counteraction to legitimization of income of bank clients", as it is quite logical to assume that the above system consists of two main subsystems - a subsystem to prevent legitimization of income and a subsystem to counteract to legitimization of income. 


\section{ENTREPRENEURSHIP AND SUSTAINABILITY ISSUES}

ISSN 2345-0282 (online) http://jssidoi.org/jesi/

2021 Volume 8 Number 4 (June)

http://doi.org/10.9770/jesi.2021.8.4(41)

\section{Research Methodology and Data}

The theoretical and methodological basis of the study are the fundamental theses of economic theory, finance theory, systems theory, research results of domestic and foreign scientists on combating money laundering, preventing and counteracting to legitimization of illegal income, financial monitoring systems, as well as general and special methods of cognition of the processes of identification, development and evaluation of processes and systems related to anti-money laundering. In particular, methods of statistical and coefficient analysis were used to solve the tasks set in the work - to determine the status and dynamics of macroeconomic factors in the legitimization of criminal income of bank clients.

One of the hypotheses of the study is that the level of risk of using the banking services to legitimize the income of its clients and the level of development of the system of prevention and counteraction to legitimization are interrelated and have an inverse relationship, i.e. the higher the level of development of the system of legitimization of income, the lower the risk of using the services of the bank for legitimization of income.

The sample of banks for in-depth analysis of cash transactions as priority ones in terms of minimizing the risk of legitimization of income of clients includes 16 banks or $20.78 \%$ of the total number of operating banks, which is a representative sample from a statistical point of view. The National Bank of Ukraine has started to provide extended data on withdrawal and crediting of funds to various accounts of Ukrainian banks (Balance sheet of the bank in accordance with Annex 1 to the Resolution of the Board of the National Bank of Ukraine "On publication of certain information on activity of banks of Ukraine" in accordance with data of statistical reporting by form № 10 (file 02) and data submitted to the National Bank of Ukraine in accordance with the Procedure for preparation, submission and publication of financial statements by banks of the Board of the National Bank of Ukraine (2017)) from August 2017, so the amount of data available for analysis as of May 2019 is 20 periods (monthly data).

The standardized measure of risk is the coefficient of variation of a random variable. According to the statistics (Sciurba 2018), it is more than 0.25 (Lee 2019). In addition, a certain predictability of the turnover of funds, and, accordingly, the controllability of this process, can be determined by the compliance of distribution of the time series with the normal one. It is believed that the normal distribution indicates that the random variable depends on the systematic action of certain factors that can be detected and evaluated, and statistical procedures are the most developed for the normal distribution of a random variable. To check the compliance of data on cash turnover and funds on current accounts of clients with the normal law, the coefficients of excess, asymmetry and the value of the Shapiro-Wilk test were analyzed, which was chosen due to the fact that the sample size for each indicator does not exceed 20.

Calculations and economic-mathematical modeling were carried out using Microsoft Excel 2016 and Statistica 10.0 software product.

The information base of the study consisted of the documents of the group for the development of financial measures to counteract money laundering (hereinafter FATF), legal and regulatory acts of Ukraine, data of the State Financial Monitoring Service of Ukraine, the State Statistics Service of Ukraine, the National Bank of Ukraine, the Ministry of Finance of Ukraine, materials from the official websites of banks, materials of professional financial associations.

The purpose of the work is the further development of theoretical principles, development of methodical support and practical recommendations for the development of a system to prevent and counteract to legitimization of income of bank clients. Achieving the purpose of the study involves solving such tasks: to analyze the financial activities of Ukrainian banks to identify the risk of money laundering; to form methodical support for risk 


\section{ENTREPRENEURSHIP AND SUSTAINABILITY ISSUES}

ISSN 2345-0282 (online) http://jssidoi.org/jesi/

2021 Volume 8 Number 4 (June)

http://doi.org/10.9770/jesi.2021.8.4(41)

assessment of the use of banking services for money laundering; to provide practical recommendations for improving the existing bank systems to prevent and counteract money laundering.

\section{Results}

Building a system of prevention and counteraction to legitimization of income of bank clients is an urgent task of development of the system of financial monitoring of Ukraine. For its effective implementation, it is necessary, firstly, to assess the actual state and activities of banks concerning prevention and counteraction to legitimization, secondly, to analyze the experience of other countries in this field and identify its advantages, which can be used and applied in Ukraine, thirdly, to sum up regulatory requirements and restrictions, both international and local, for their further consideration, fourthly, using a systematic approach, to determine whether the appropriate systems are created in Ukrainian banks, and finally, to improve existing systems of prevention and counteraction to legitimization of suspicious income in banks, or create new ones based on the results of the above tasks.

Therefore, the creation of a system of prevention and counteraction to legitimization of income of bank clients should be preceded by large-scale analytical and evaluation activities, the results of which create an appropriate information basis. In this context, the issue and tasks of assessing the system of prevention and counteraction to legitimization of income of bank clients in the past and current periods become urgent. This task can be performed provided that there are appropriate guidelines and effective tools, which exist only in fragments, which necessitated the creation of a integrated, scientifically sound methodical approach to assessing the system of prevention and counteraction to legitimization of income of bank clients.

The main difference between prevention and counteraction to to legitimization of income is that counteraction occurs only when there is an action aimed at money laundering. Thus, it is advisable to consider the prevention of the legitimization of income of bank clients as a set of previously taken actions of a bank to prevent an individual or a legal entity from taking any actions with money and other financial assets obtained as a result of illegal and related activities in order to hide their origin and turn them into legal assets through the use or attempt to use the services of a bank.

Counteraction to the legitimization of income of bank clients is a set of actions of a bank that directly prevent an individual or a legal entity from taking any actions with money and other financial assets obtained as a result of illegal and related activities, in order to hide their origin and turn them into legal assets through the use or attempt to use the services of a bank.

The above definitions allow to establish such differences of prevention from counteraction to legitimization of income of bank clients: prevention involves a pre-built system of actions, measures, the operation of which is aimed at prevention of legitimization, while counteraction is carried out at the time of clients attempting to legitimize their income, although it can and should be based on a pre-built system of actions and measures; prevention is preventive in nature, while counteraction has the nature of an action that stops or prevents the other actions.

The banking system of Ukraine is attractive for criminals to carry out money laundering operations, while the financial monitoring services of banks were insufficiently efficient until 2018. This is confirmed by statistics on reports of suspicious financial transactions (Figure 1). 


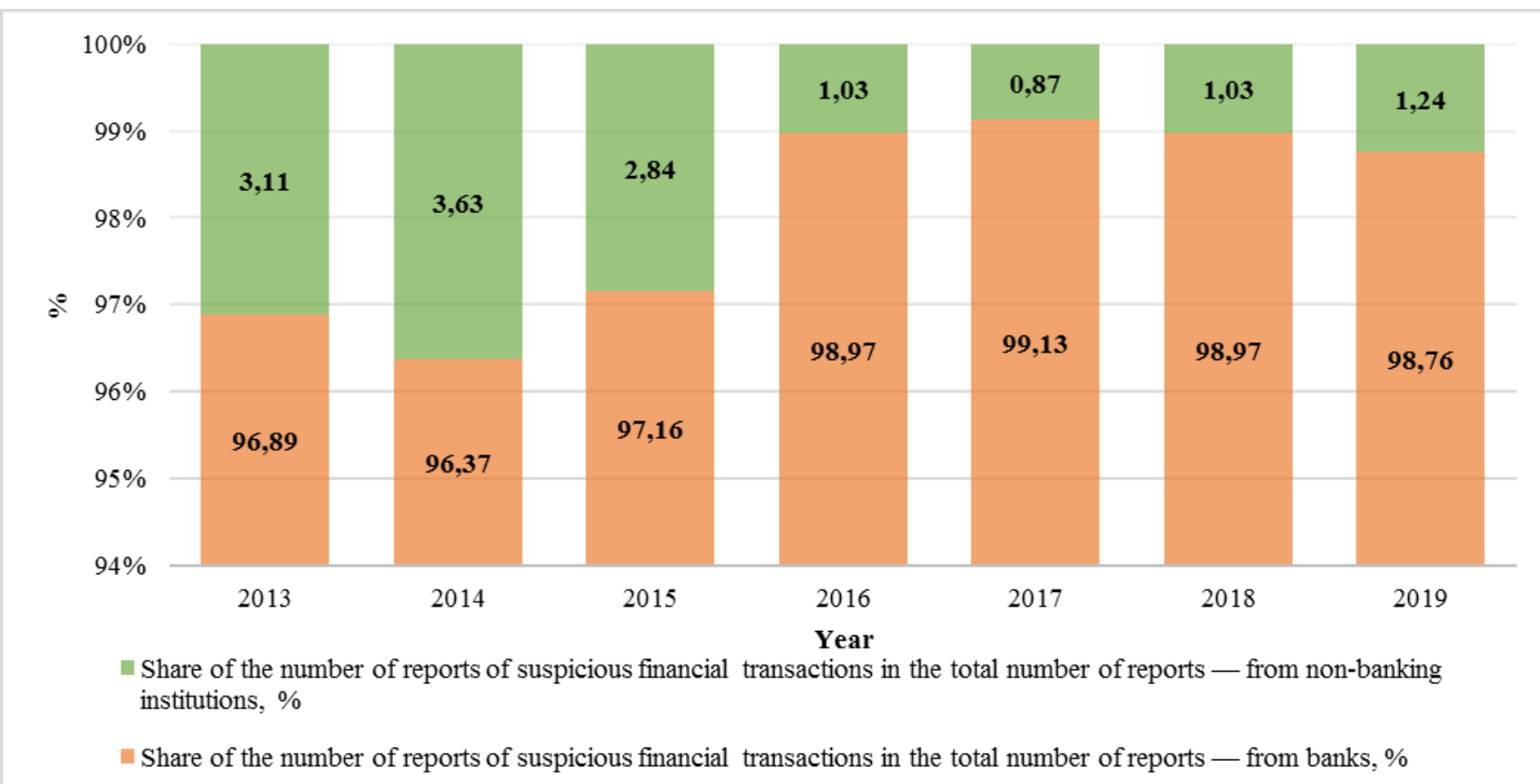

Fig. 1. Dynamics of the number of reports on financial transactions to the SCFM by types of entities of primary financial monitoring for the period of 2013-2019

Source: authors' calculations according to "Six financial institutions voluntarily renounced licenses" (2021)

The data in Figure 1 shows that of all the reports of suspicious financial transactions sent, 96-99\% are just from banking institutions ("Six financial institutions voluntarily renounced licenses" 2021). The generalization of information from these reports is the basis for the formation by the State Financial Monitoring Service of materials for further referral to various law enforcement agencies, including investigative bodies, prosecution agencies, the National Anti-Corruption Bureau. Based on the data in Figure 1, it can be argued that among all the entities of primary financial monitoring, banks create $96 \%$ or more of the information field for prevention and counteraction to legitimization of proceeds of crime. Thus, an important task of further improvement of the system of prevention and counteraction to legitimization of proceeds of crime at the state level is the formation of an appropriate system at the bank level.

The group of economic factors includes: the level of official income of the population, the existence and volume of unofficial income or the level of the shadow economy. Thus, the level of official income of the population is a disincentive to money laundering: the higher the official income, the lower the volume (intentions) of money laundering. The existence and volumes of unofficial incomes of the population, criminal incomes of criminal groups. This factor is a stimulant of money laundering: the higher the level of the shadow economy of a country, the higher the risks of money laundering.

From the point of view of measuring and evaluating the factors of a country at the international level, it is advisable to resort to a comparative approach and use international official ratings, which are formed by recognized international organizations, unions, associations or groups of scientists. Thus, if we use the data (the level of the shadow economy in Ukraine was $47 \%$ of GDP in 2018, according to a study of 2019) on the level of the shadow economy of separate countries in 2018 and compare it with the data on Ukraine, it becomes clear that the level of the shadow economy is much higher in Ukraine. It is 6.3, 5.7, and 1.6 times higher than that of the shadow economy of the USA, Switzerland and Greece, respectively (Figure 2). 


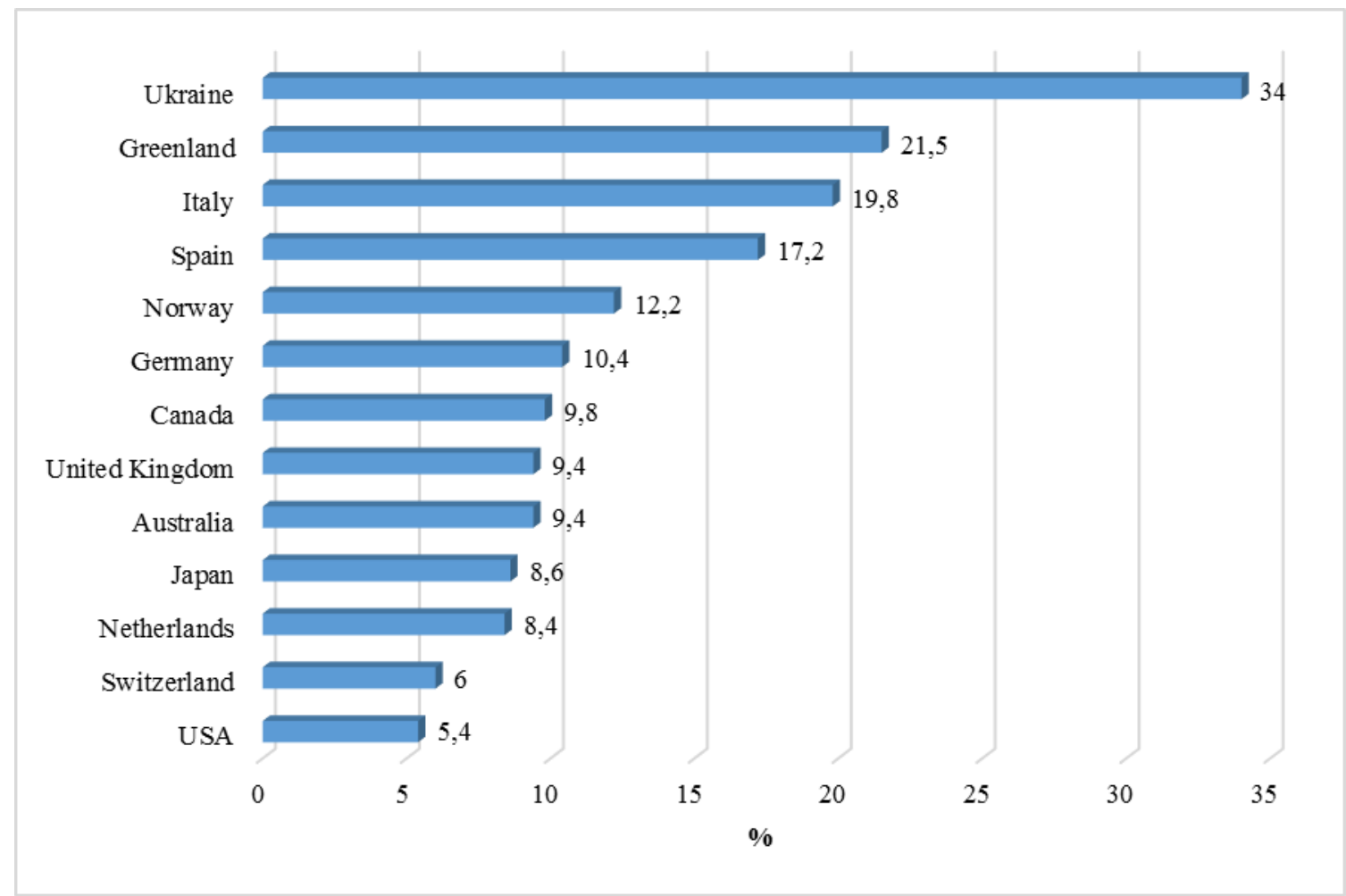

Fig. 2. Level of shadow economy of separate world countries in 2019

Source: built by the authors according to the data (the level of the shadow economy in Ukraine was $47 \%$ of GDP in 2018, according to a study of 2019)

It should be noted that for 10 years (from 2008 to 2018) the leading countries of the world have made significant efforts to combat money laundering, which has had a positive impact on the level of the shadow economy. In Canada, Germany, Switzerland, the USA and New Zealand, the shadow economy declined by more than $22 \%$ from 2007 to 2017. Australia, Austria, Ireland, Norway and Finland have reduced the shadow economy by almost $20 \%$ of GDP: $19.7 \% ; 19.1 \% ; 18.1 \% ; 20.8 \% ; 20.7 \%$ respectively.

It should be noted that the group of factors of legitimization of proceeds of crime, which is specified in the documents, is a set of factors directly related to the operations of banks and the financial instruments used. Special attention needs to be paid to anonymous operations (prohibited by law in Ukraine); cash transactions and electronic bank transfers, as well as transactions with cryptocurrencies, as they combine signs of anonymity, uncontrollability, high speed of movement of valuables.

Indicators that may reflect the presence and significance of the impact of food factors on anti-money laundering processes may be: the volumes of money supply in cash; the share of cash money supply in GDP; the share of cash in the total money of the country; the volumes of cash banking transactions; the share of cash banking transactions in the total volume of transactions; balances of funds in cryptocurrency wallets declared by individuals. In Figure 3, the analysis of the dynamics of cash turnover in Ukraine for 2009-2019 is presented. 
ENTREPRENEURSHIP AND SUSTAINABILITY ISSUES

ISSN 2345-0282 (online) http://jssidoi.org/jesi/

2021 Volume 8 Number 4 (June)

http://doi.org/10.9770/jesi.2021.8.4(41)

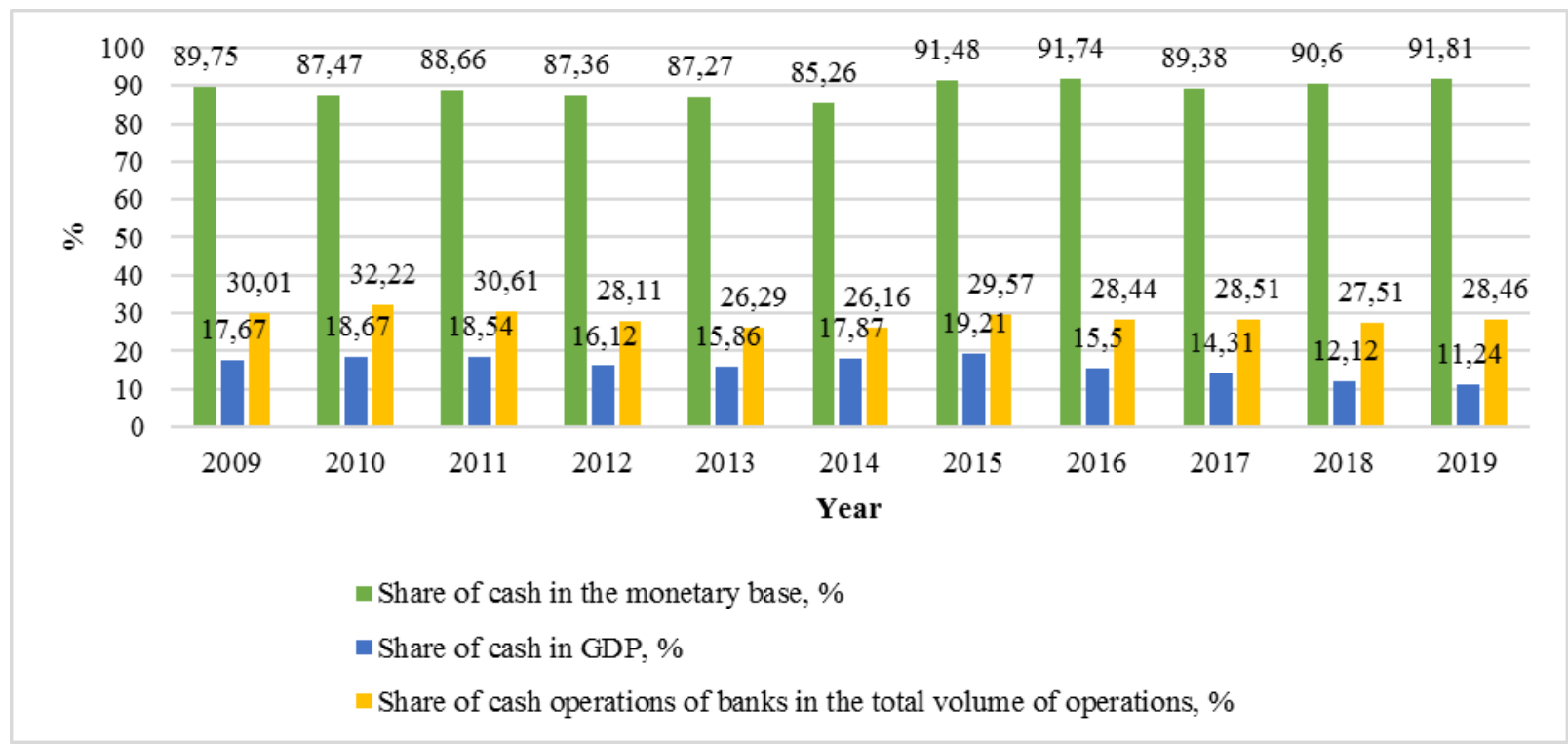

Fig. 3. Dynamics of cash turnover in Ukraine for 2009-2019

Source: calculated by the authors according to the data (Rating of reliable banks of Ukraine 2021)

The data presented in Figure 3 show that in Ukraine the amount of cash in circulation for 2009-2019 exceeds $84 \%$, which is a very high figure compared to leading European countries. For 2018-2019, the share of cash in the monetary base increased to $92 \%$. As of the beginning of 2015, one sixth of GDP was in cash, and in 2019 the share of cash in GDP decreased to $11.24 \%$. One third of banking operations are carried out with cash or in cash, and the situation has not changed over the last ten years, which can contribute to both the shadowing of the economy and the process of money laundering. Regarding the volume of cash transactions outside the banking system and the so-called illegal cash, according to Acting Chairman of the NBU as of July 2017, its volume reached UAH 300 billion, which is $87 \%$ of the total amount of cash issued (Rating of reliable banks of Ukraine 2021).

In order to assess the risk of legitimization of proceeds of crime using the banking services, in particular cash transactions, the volumes of crediting and withdrawing cash, as well as the volumes of transactions on demand accounts (meaning demand accounts of individuals and demand accounts of business entities) in the banks of Ukraine, which had significant shortcomings at the time of the NBU inspection, were analyzed. During 20152019 , the most vulnerable components of the system of prevention and counteraction to legitimization of income of clients of Ukrainian banks were: analysis, detection, registration of financial transactions subject to financial monitoring; identification, verification and study of clients; risk management. Totally, there were 96 banks with shortcomings in their activities aimed at preventing and combating money laundering in 2016-2019. Some banks have been inspected for several years in a row, and some banks were liquidated. Therefore, for a set of justifications for banks, the operations of which should be analyzed in depth, it is advisable to identify those that had the most significant shortcomings or signs of money laundering.

The analysis of the obtained statistical characteristics of time series concerning volumes of deposit and withdrawal of cash and non-cash means from accounts of clients of bank allows to reveal the increased risk of legitimization of incomes. As an example, we show the statistical indicators of PJSC JSCB "CONCORD" (Table $1)$. 


\section{ENTREPRENEURSHIP AND SUSTAINABILITY ISSUES}

ISSN 2345-0282 (online) http://jssidoi.org/jesi/

2021 Volume 8 Number 4 (June)

http://doi.org/10.9770/jesi.2021.8.4(41)

Table 1. Statistical characteristics of a time series of cash turnover and funds on accounts at the request of PJSC "JSCB" CONCORD from 01.09.2017 to 01.04 .2019

\begin{tabular}{|c|c|c|c|c|c|c|}
\hline \multirow{3}{*}{ Indicator } & \multicolumn{4}{|c|}{ Cash } & \multirow{2}{*}{\multicolumn{2}{|c|}{$\begin{array}{c}\text { Company demand funds } \\
\text { Credit of funds }\end{array}$}} \\
\hline & \multicolumn{2}{|c|}{ Deposit into an account } & \multicolumn{2}{|c|}{ Withdrawal from an account } & & \\
\hline & $\mathrm{NC}$ & $\mathrm{FC}$ & $\mathrm{NC}$ & $\mathrm{FC}$ & $\mathrm{NC}$ & FC \\
\hline Average value & 386,271 & 133,077 & 382,655 & 128,806 & $1,843,766$ & 449,892 \\
\hline Median value & 357,635 & 96,336 & 356,903 & 94,313 & $1,728,895$ & 343,768 \\
\hline Minimum value & $245,716.5$ & $20,529.0$ & $255,489.0$ & $21,681.3$ & $955,925.1$ & $237,911.7$ \\
\hline Maximum value & 743,074 & 485,005 & 677,605 & 428,716 & $2,967,277$ & $1,276,587$ \\
\hline Standard deviation & $123,292.0$ & $125,477.2$ & $110,547.1$ & $117,684.9$ & $624,436.6$ & $257,171.8$ \\
\hline Variation coefficient & 0.3192 & 0.9429 & 0.2889 & 0.9137 & 0.3387 & 0.5716 \\
\hline Asymmetry ratio & 2.08 & 1.70 & 1.94 & 1.50 & 0.39 & 1.98 \\
\hline Standard asymmetry error & 0.51 & 0.51 & 0.51 & 0.51 & 0.51 & 0.51 \\
\hline Excess coefficient & 4.35 & 2.48 & 3.76 & 1.50 & -1.16 & 4.70 \\
\hline Standard excess error & 0.99 & 0.99 & 0.99 & 0.99 & 0.99 & 0.99 \\
\hline Shapiro-Wilk test & 0.74995 & 0.79438 & 0.76486 & 0.80685 & 0.93057 & 0.78332 \\
\hline P-value of Shapiro-Wilk test & 0.00017 & 0.00071 & 0.00027 & 0.0011 & 0.15835 & 0.00049 \\
\hline \multirow{3}{*}{ Indicator } & \multicolumn{2}{|c|}{ Demand funds of companies } & \multicolumn{4}{|c|}{ Demand funds of individuals } \\
\hline & \multicolumn{2}{|c|}{ Withdrawal of funds } & \multicolumn{2}{|c|}{ Withdrawal of funds } & \multicolumn{2}{|c|}{ Credit of funds } \\
\hline & $\mathrm{NC}$ & $\mathrm{FC}$ & $\mathrm{NC}$ & $\mathrm{FC}$ & $\mathrm{NC}$ & FC \\
\hline Average value & $1,849,656$ & 451,068 & 136,572 & 55,410 & 138,458 & 58,249 \\
\hline Median value & $1,709,254$ & 345,769 & 128,810 & 43,129 & 129,269 & 47,689 \\
\hline Minimum value & $978,754.6$ & $220,542.9$ & $68,190.2$ & $7,051.1$ & $67,401.2$ & $8,037.5$ \\
\hline Maximum value & $2,934,153$ & $1,287,751$ & 242,675 & 169,643 & 242,746 & 185,532 \\
\hline Standard deviation & $622,486.7$ & $257,164.0$ & $47,929.4$ & $41,669.2$ & $48,603.7$ & $45,571.5$ \\
\hline Variation coefficient & 0.3365 & 0.5701 & 0.3509 & 0.7520 & 0.3510 & 0.7824 \\
\hline Asymmetry ratio & 0.41 & 2.05 & 0.47 & 1.44 & 0.41 & 1.66 \\
\hline Standard asymmetry error & 0.51 & 0.51 & 0.51 & 0.51 & 0.51 & 0.51 \\
\hline Excess coefficient & -1.17 & 5.08 & -0.25 & 1.97 & -0.20 & 2.69 \\
\hline Standard excess error & 0.99 & 0.99 & 0.99 & 0.99 & 0.99 & 0.99 \\
\hline Shapiro-Wilk test & 0.92551 & 0.78482 & 0.96059 & 0.86482 & 0.96072 & 0.8294 \\
\hline P-value of Shapiro-Wilk test & 0.12654 & 0.00052 & 0.55573 & 0.00954 & 0.55831 & 0.00245 \\
\hline
\end{tabular}

Source: authors' calculations based on ("Six financial institutions voluntarily renounced licenses" 2021)

Notes: NC — national currency of Ukraine, FC - foreign currency

The data presented in Table 1 show that there is a high risk of money laundering by clients of PJSC "JSCB "Concord", as the value of the covariance coefficient for the entire analyzed period for all indicators was not less than 0.28 , and for the accounts of individuals in foreign currency the variation more than 0.75 . The asymmetry for all values is positive, which indicates the location of most of the data to the right of the mathematical expectation. In statistics, it is believed (Wetzel \& Luciano 2017) that "events for which excess is maximum are burdened with minimum risk".

For PJSC "JSCB "Concord" (Table 2), this means that the lowest risk of money laundering is associated with operations related to withdrawal (or write-off) and crediting funds in foreign currency to the accounts of economic 
entities. To compare the calculated values of the Shapiro-Wilk test with the table ones, the corresponding calculations were carried out, the results of which are presented in Table 2.

Table 2. Value of the Shapiro-Wilk test for 20 observations

\begin{tabular}{|l|c|c|c|}
\hline \multirow{2}{*}{ Indicator } & \multicolumn{3}{|c|}{ Significance level } \\
\cline { 2 - 4 } & 0.01 & 0.05 & 0.1 \\
\hline Shapiro-Wilk test for 20 observations & 0.2167 & 0.4230 & 0.5422 \\
\hline
\end{tabular}

Source: authors' calculations based on ("Six financial institutions voluntarily renounced licenses" 2021)

If the calculated value of the test is greater than the table ones (Table 2), it is assumed that the analyzed value is distributed normally. Therefore, according to the Shapiro-Wilk test, the values of cash and non-cash funds of clients of PJSC "JSCB "Concord" are normally distributed, which allows to apply parametric methods of analysis for the bank data. To check the closeness of the relationship between the crediting and withdrawal of funds from accounts, the coefficient of pair correlation between the amounts of crediting funds to the respective accounts and the amounts of withdrawals from the accounts of clients of PJSC "JSCB "Concord" was used, and the results of calculations carried out by the author are presented in Table 3.

Table 3. Coefficients of pair correlation between indicators of cash and non-cash flows of clients of PJSC "JSCB "Concord"

\begin{tabular}{|l|c|c|c|c|c|c|}
\hline \multicolumn{1}{|c|}{ Indicator } & Cash deposits & Cash withdrawals & $\begin{array}{c}\text { Deposit of funds } \\
\text { into demand } \\
\text { accounts of a } \\
\text { company }\end{array}$ & $\begin{array}{c}\text { Withdrawal } \\
\text { of funds from } \\
\text { demand accounts } \\
\text { of a company }\end{array}$ & $\begin{array}{c}\text { Deposit of funds } \\
\text { into demand } \\
\text { accounts of } \\
\text { individuals }\end{array}$ & $\begin{array}{c}\text { Withdrawal } \\
\text { of funds from } \\
\text { demand accounts } \\
\text { of individuals }\end{array}$ \\
\hline Cash deposits & 1.0000 & 0.9940 & 0.5756 & 0.5769 & 0.7983 & 0.8368 \\
\hline Cash withdrawals & 0.9940 & 1.0000 & 0.5910 & 0.5944 & 0.7887 & 0.8278 \\
\hline $\begin{array}{l}\text { Deposit of funds } \\
\text { into demand } \\
\text { accounts of a }\end{array}$ & 0.5756 & 0.5910 & 1.0000 & 0.9980 & 0.4793 \\
\hline $\begin{array}{l}\text { Withdrawal } \\
\text { of funds from } \\
\text { demand accounts of }\end{array}$ & 0.5769 & 0.5944 & 0.9980 & 1.0000 & 0.4823 \\
\hline $\begin{array}{l}\text { Deposit of funds } \\
\text { into demand } \\
\begin{array}{l}\text { accounts of } \\
\text { individuals }\end{array}\end{array}$ & 0.7983 & 0.7887 & 0.4793 & 0.4823 & 1.0000 \\
\hline $\begin{array}{l}\text { Withdrawal } \\
\text { of funds from } \\
\text { demand accounts of } \\
\text { individuals }\end{array}$ & 0.8368 & 0.8278 & 0.4881 & 0.4922 & 0.4922 \\
\hline
\end{tabular}

Source: authors' calculations based on ("Six financial institutions voluntarily renounced licenses" 2021)

The data presented in Table 3 show that crediting and withdrawing funds are closely related, as the coefficients of pair correlation between the indicators of one group are 0.99 and more. Also, the data presented in Table 3 allow to see that in PJSC "JSCB "Concord" cash flow is more closely related to the accounts of individuals than the flow of funds of enterprises and organizations. 


\section{ENTREPRENEURSHIP AND SUSTAINABILITY ISSUES}

ISSN 2345-0282 (online) http://jssidoi.org/jesi/

2021 Volume 8 Number 4 (June)

http://doi.org/10.9770/jesi.2021.8.4(41)

The authors' calculations of statistical characteristics of the time series of cash turnover and turnover of funds on the accounts of bank clients - business entities and individuals showed that banks, in the activities of which scheme operations are detected, have mostly high values of the coefficient of variation (on average $25 \%$ ).

The conducted analysis showed that the coefficient of variation of the flow of funds in the accounts of bank clients and cash flow can be used as an indicator of the risk of money laundering.

\section{Discussion}

Ukraine belongs to the group of countries with an increased risk of money laundering and terrorist financing: It is characterized by a high level of shadow economy, a very high percentage of cash in circulation and cash transactions of banks, low incomes, a significant number and participation of officials in economic processes. The main recommendations that should be implemented in Ukraine to reduce the risk of money laundering, terrorist financing and/or financing the proliferation of weapons of mass destruction (AM/FT) are: a ban on transactions with countries and residents of countries with the highest values (more than 7.5 out of a maximum of 10) of the Basel Anti-Money Laundering Index; high fines for banks in case of detection of transactions with clients, which on certain grounds should be classified as high-risk in terms of legitimization of income, formalize in legislation the application of the measure of revocation of bank licenses in case of systematic violation of current legislation on financial monitoring.

The approach to assessing the risk of money laundering is based on a risk score and has 15 indicators that take into account certain aspects of suspicious financial transactions and personnel involvement in money laundering and does not take into account such important components as internal control, internal and external audit, compliance, personnel competence, corporate governance, information systems management, which also significantly affect the level of risk of the bank regarding money laundering (Kostyuchenko et. al 2018).

In the evaluation process, it is proposed to take into account the following aspects that relate directly to banks: the procedure for client identification and analysis; monitoring and reporting on financial transactions; internal control, internal and external audits; compliance; personnel training and recruitment (or personnel competence), as well as national factors: legislative support, institutional support and prevention infrastructure (Nikkinen J. 2017).

When forming a methodical approach to the evaluation of the system of prevention and counteraction to legitimization of income of bank clients, it is important to determine the essence and content of the object of evaluation.

Minimization of risks of legitimization of income is one of the goals of the system of prevention and counteraction to legitimization of income of bank clients. The evaluation of the risk of using banking services for the purpose of money laundering makes it possible to determine the extent to which this goal has been achieved (Abu 2019).

In our opinion, the risk management of Ukrainian banks taking into account the expanded analysis of assessments of its components requires the following recommendations for improvement:

1. In the procedure for analysis of the risk of legitimization of income of bank clients, change the frequency of its conducting from once in nine months to once in six months.

2. To oblige the new products development department to carry out their examination of the risk of such products in relation to the risk of money laundering with the participation of the financial monitoring unit of the bank.

3. To oblige the bank marketing department to carry out an examination of future locations of separate bank divisions for the geographical component of the risk of money laundering. 


\title{
ENTREPRENEURSHIP AND SUSTAINABILITY ISSUES
}

ISSN 2345-0282 (online) http://jssidoi.org/jesi/

2021 Volume 8 Number 4 (June)

http://doi.org/10.9770/jesi.2021.8.4(41)

4. To set a high level of risk for all new products and services of the bank until their examination with the participation of the financial monitoring unit.

The developed recommendations for improving the most problematic components of systems to prevent and combat legitimization of income of bank clients create a scientifically sound basis for further development of these systems and reduce the risk of using the services of analyzed banks to legitimize suspicious incomes of their clients.

\section{Conclusions}

The conducted analysis of indicators reflecting the economic factors of legitimization of income for 2011-2018 revealed a declining trend in real GDP per capita and a consistently high level of the shadow economy (32$40 \%$ ), which contributes to the strengthening of legitimization processes. Along with the macroeconomic factors of legitimization of income, there are client and operational factors. Client factors are characterized by qualitative indicators of clients of the entities of primary financial monitoring, such as: type of activity of the legal entity, composition and residence of the beneficial owners, sphere of the main employment of the individual (for example, political and other public figures), purpose of opening of accounts.

The effect of operational factors can be traced by the indicators of cash volumes in the country, the volumes of cash transactions of the entities of primary financial monitoring. In the paper, it was found that in Ukraine, starting from 2009, the share of cash in the money supply increases from $84.9 \%$ (2009) to $91.81 \%$ (2019), but the share of cash operations of banks in the total volume decreases - from $30.01 \%$ to $28.46 \%$, and so does the share of cash in GDP - from $15.09 \%$ to $11.24 \%$.

The conducted analysis showed that the coefficient of variation of the flow of funds in the accounts of bank clients and cash flows can be used as an indicator of the risk of money laundering. In the paper, it was proven that banks with the highest (actually detected) risk of legitimization have the highest values of coefficients of variation - up to $120 \%$ Based on the obtained results and taking into account the in-depth analysis of the most problematic components of the systems of prevention and counteraction to legitimization of income of bank clients, there have been developed appropriate recommendations for the improvement of the analyzed banks.

\section{References}

Abu, E. A. (2019). Definition of legalization (laundering) of proceeds from crime. Legea şi Viaţa, 331(7/2), 3-6. Retrieved from: https://ibn.idsi.md/vizualizare_articol/82174

\begin{abstract}
Balance sheet of the bank in accordance with Annex 1 to the Resolution of the Board of the National Bank of Ukraine "On publication of certain information on activity of banks of Ukraine" in accordance with data of statistical reporting by form № 10 (file 02) and data submitted to the National Bank of Ukraine in accordance with the Procedure for preparation, submission and publication of financial statements by banks of the Board of the National Bank of Ukraine. With change (2017). Resolution of the Board of the National Bank of Ukraine No. 85, August 31, 2017. Retrieved from: https://bank.gov.ua/statistic/supervision-statist/data-supervision\#4
\end{abstract}

Current methods and ways of legitimization (laundering) of proceeds of crime and terrorist financing (2014). Financial Investigations Department, State Financial Monitoring Service of Ukraine. Retrieved from: http://finmonitoring.in.ua/wpcontent/uploads/2018/04/tipologichni-doslidzhennya-ua_2014_15_16.pdf

Chong, A., \& Lopez-De-Silanes, F. (2015). Money laundering and its regulation. Economics \& Politics, 27(1), 78-123. Retrieved from: https://onlinelibrary.wiley.com/doi/abs/10.1111/ecpo.12051 


\section{ENTREPRENEURSHIP AND SUSTAINABILITY ISSUES}

ISSN 2345-0282 (online) http://jssidoi.org/jesi/

2021 Volume 8 Number 4 (June)

http://doi.org/10.9770/jesi.2021.8.4(41)

Dreżewski, R., Sepielak, J., \& Filipkowski, W. (2015). The application of social network analysis algorithms in a system supporting money $\begin{array}{lllll}\text { laundering detection. } & \text { Information } & \text { Sciences, } & \text { 295, } & \text { 18-32. }\end{array}$ https://www.sciencedirect.com/science/article/abs/pii/S0020025514009979

Habibzadeh, M. (2016). Legal strategies of money laundering prevention emphasizing Financial-Economical policies. Journal of Social Sciences and Humanities Research, 4(02), 24-28. Retrieved from: http://journals.researchub.org/index.php/JSSHR/article/view/428

Isa, Y. M., Sanusi, Z. M., Haniff, M. N., \& Barnes, P. A. (2015). Money laundering risk: from the bankers' and regulators perspectives. Procedia Economics and Finance, 28, 7-13. Retrieved from: https://www.sciencedirect.com/science/article/pii/S2212567115010758

Jaara, O. O., \& Kadomi, A. M. (2017). Factors related to the Central Bank instructions on money laundering. Journal of Money Laundering Control, 274-291.

Kostyuchenko, N., Starinskyi, M., Tiutiunyk, I., \& Kobushko, I. (2018). Methodical approach to the assessment of risks connected with the legalization of the proceeds of crime. Montenegrin Journal of Economics, 14(4), 23-43. Retrieved from: http://www.mnje.com/sites/mnje.com/files/023__043_-_kostjusenko_et_al_0.pdf

Kriviņš, A., Teivāns-Treinovskis, J. \& Tumalavičius, V. (2021). Issues of state and national security: Religiously inspired terrorism in the Baltic States: internal and external factors. Insights into Regional Development, 3(1), 65-79. http://doi.org/10.9770/IRD.2021.3.1(4)

Lee, H. W. (2019). Legalization and dispute settlement benefits: The case of the GATT/WTO. The Review of International Organizations, 14(3), 479-509. Retrieved from: https://link.springer.com/article/10.1007/s11558-018-9313-8

Nikkinen, J. (2017). The legalization of dangerous consumption: a comparison of cannabis and gambling policies in three US states. Addiction Research \& Theory, 25(6), 476-484. Retrieved from: https://www.tandfonline.com/doi/abs/10.1080/16066359.2017.1366455

Rating of reliable banks of Ukraine (2021). Forinsurer. Retrieved from: https://forinsurer.com/rating-banks

Regulation On Financial Monitoring by Banks (2015). Resolution of the Board of the National Bank of Ukraine No. 417, June 26, 2015. Retrieved from: http://zakon5.rada.gov.ua/laws/show/v0417500-15

Sciurba, M. (2018). Analysis of the public regulation Issues in implementing mechanisms to fight money laundering: international and domestic experiences. Public management, (2), 236-243.

Singh, K., \& Best, P. (2019). Anti-money laundering: using data visualization to identify suspicious activity. International Journal of Accounting Information Systems, 34, 100418. Retrieved from: https://www.sciencedirect.com/science/article/abs/pii/S146708951730043X

Six financial institutions voluntarily renounced licenses (2021). National Bank of Ukraine. Retrieved from: https://bank.gov.ua/ua/news/all/shist-finansovih-ustanov-dobrovilno-vidmovilisya-vid-litsenziy

Sobreira Leite, G., Bessa Albuquerque, A., \& Rogerio Pinheiro, P. (2019). Application of Technological Solutions in the Fight Against Money Laundering-A Systematic Literature Review. Applied Sciences, 9(22), 4800. Retrieved from: https://www.mdpi.com/2076$\underline{3417 / 9 / 22 / 4800}$

Teichmann, F. (2020). Recent trends in money laundering. Crime, Law and Social Change, 73(2), 237-247. Retrieved from: https://link.springer.com/article/10.1007/s10611-019-09859-0

The level of the shadow economy in Ukraine was $47 \%$ of GDP in 2018, according to a study of 2019. Economic pravda. Retrieved from: https://www.epravda.com.ua/news/2019/10/11/652509/

Tsingou, E. (2018). New governors on the block: the rise of anti-money laundering professionals. Crime, Law and Social Change, 69(2), 191-205. Retrieved from: https://link.springer.com/article/10.1007/s10611-017-9751-x

Wetzel, C., \& Luciano, K. (2017). From Community Cancer to Common Entertainment: The Dynamics of Lottery Legalization in Massachusetts. Sociological Inquiry, 87(1), 5-26. Retrieved from: https://onlinelibrary.wiley.com/doi/abs/10.1111/soin.12157 


\section{ENTREPRENEURSHIP AND SUSTAINABILITY ISSUES}

ISSN 2345-0282 (online) http://jssidoi.org/jesi/

2021 Volume 8 Number 4 (June)

http://doi.org/10.9770/jesi.2021.8.4(41)

Stanislav ZLYVKO, Doctor of Sciences (Law), Professor of the Department of Administrative, Civil and Commercial Law and Process, Academy of the State Penitentiary Service

ORCID ID: orcid.org/0000-0003-2732-3144

Serhii SHKLIAR, Managing Partner, Arzinger Law Firm

ORCID ID: orcid.org/0000-0003-2351-0161

Anatoliy KOVALENKO, Doctor of Law, Associate Professor, Associate Professor of the Department of Public Law Disciplines of a Private Institution of Higher Education, Kyiv International University

ORCID ID: orcid.org/0000-0003-3805-0989

Maksym SYKAL, PhD in Law, Associate Professor of the Department of Administrative, Civil and Commercial Law and Process, Academy of the State Penitentiary Service

ORCID ID: orcid.org/0000-0003-0334-4047

Oleksandr SNIGEROV, Doctor of juridical sciences, Professor, Principal Researcher at the Hon. Prof. M. S. Bokarius Kharkiv Research Institute of Forensic Examinations of the Ministry of Justice of Ukraine

ORCID ID: orcid.org/0000-0002-7303-2383

Make your research more visible, join the Twitter account of ENTREPRENEURSHIP AND SUSTAINABILITY ISSUES: @Entrepr69728810

Copyright (C) 2021 by author(s) and VsI Entrepreneurship and Sustainability Center

This work is licensed under the Creative Commons Attribution International License (CC BY).

http://creativecommons.org/licenses/by/4.0/

(c) (7) Open Access 